\title{
Correction: Improving the standards-based management: recognition initiative to provide high-quality, equitable maternal health services in Malawi. An implementation research protocol
}

Mumtaz Z, Salway S, Nyagero J, et al. Improving the standards-based management: recognition initiative to provide high-quality, equitable maternal health services in Malawi. An implementation research protocol. BMJ Global Health 2016;1:e000022. This article has been corrected since it was first published; the title has been corrected to: Improving the Standards-Based Management-Recognition initiative to provide high-quality, equitable maternal health services in Malawi: an implementation research protocol.

Open Access This is an Open Access article distributed in accordance with the Creative Commons Attribution Non Commercial (CC BY-NC 4.0) license, which permits others to distribute, remix, adapt, build upon this work noncommercially, and license their derivative works on different terms, provided the original work is properly cited and the use is non-commercial. See: http://creativecommons.org/licenses/by-nc/4.0/

BMJ Global Health 2016;1:e000022. doi:10.1136/bmjgh-2015-000022corr1

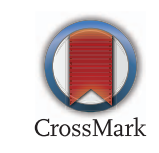

